\title{
Genetic dissection of Alzheimer's disease and related dementias: amyloid and its relationship to tau
}

John Hardy, Karen Duff, Katrina Gwinn Hardy, Jordi Perez-Tur and Mike Hutton

Nature Neurosci 1, 355-358 (1998).

In preparing Table 1, an old version with incomplete data was inadvertantly used. The correct version is shown here. The authors regret the error.

\begin{tabular}{|c|c|c|c|c|c|}
\hline Mutation type & Mutations & Soluble tau & Tau inclusions & Tau filaments & Glial inclusions? \\
\hline $\begin{array}{l}\text { Missense } \\
\text { NOT exon } 10\end{array}$ & $\begin{array}{c}\text { G272V, } \\
\text { V337M, R406W }\end{array}$ & $\begin{array}{l}\text { Normal ratio of } \\
4 \text { to } 3 \text { repeat }\end{array}$ & All six isoforms & AD -like $\mathrm{PH} \mathrm{F}^{* * *}$ & No \\
\hline $\begin{array}{l}\text { Missense } \\
\text { in exon } 10\end{array}$ & P301L & $\begin{array}{l}\text { Normal ratio of } \\
4 \text { to } 3 \text { repeat** }\end{array}$ & $\begin{array}{c}4 \text { repeat } \\
\text { predominates }\end{array}$ & $\begin{array}{l}\operatorname{LPF}^{* * *} \text { ('Twisted } \\
\text { ribbons') }\end{array}$ & Yes \\
\hline $\begin{array}{l}\text { Exon } 10 \\
\text { 5' splice site }\end{array}$ & $\begin{array}{c}+13^{*} \\
+14^{*} \\
+16^{*} \\
+3^{*}\end{array}$ & $\begin{array}{l}\text { Increased } 4 \\
\text { repeat }\end{array}$ & $\begin{array}{c}4 \text { repeat } \\
\text { predominates }\end{array}$ & $\begin{array}{l}\operatorname{LPF}^{* * *}(\text { ('Twisted } \\
\text { ribbons') }\end{array}$ & Yes \\
\hline
\end{tabular}

* Exon 10 5'-splice-site mutations numbered from 3' end of exon 10

**Inferred from unchanged ratio of exon $10+/$ - RN A

***LPF, long periodicity filaments; PHF, paired helical filaments

Proposed relationship between site of mutation in tau gene and type of pathogenic tau mutation. Proposal based on data taken from refs 50 - 54 and unpublished data from the authors' laboratories.

\section{Gap-junction-mediated propagation and amplification of cell injury}

Jane H.-C. Lin, Helga Weigel, Maria Luisa Cotrina, Shujun Liu, Earl Bueno, Anker J. Hansen, Thomas W. Hansen, Steven Goldman and Maiken Nedergaard

Nature Neurosci. 1, 494-500 (1998).

In preparing Fig. $5 \mathrm{~g}$ and $\mathrm{h}$, the bars were inadvertantly colored incorrectly. The correct version is shown here. The authors regret the error.

Fig. 5

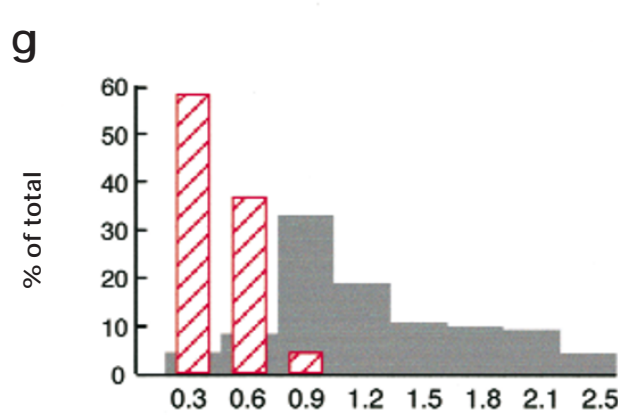

h

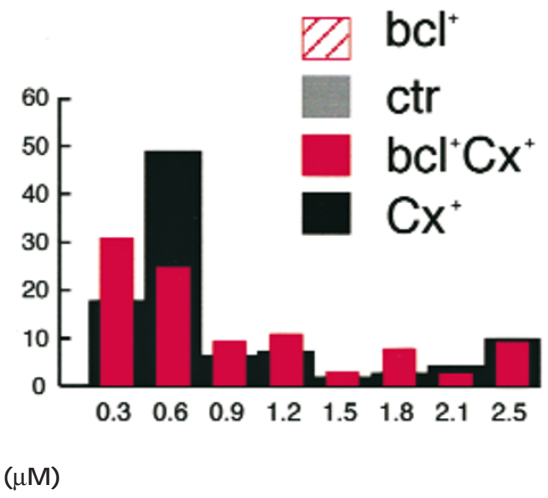

errata

\section{Functional anatomy of saccadic adaptation in humans}

M. Desmurget, D. Pélisson, C. Urquizar, C. Prablanc, G.E. Alexander and S.T. Grafton

Nature Neurosci. 1, 524-528 (1998).

Because of an editorial error, the last line of the Discussion section was misprinted. The sentence should read as follows:

From a theoretical point of view, the congruence between our data and observations emphasizing the role of the medial cerebellum for saccadic adaptation in monkeys supports the hypothesis that saccadic adaptation involves similar neural circuits in humans and animals. 